\title{
НАУКОВО-МЕТОДИЧНІ ПІДХОДИ ДО РЕАЛІЗАЦІЇ ЗМІСТУ ОСВІТИ УЧНІВ ІЗ ПОРУШЕННЯМИ ІНТЕЛЕКТУАЛЬНОГО РОЗВИТКУ ЗГІДНО КОНЦЕПЦІЇ НУШ
}

Олена Чеботарьова, Інститут спеціальної педагогіки та психології імені Миколи Ярмаченка Національна академія педагогічних наук України, м. Київ, Україна

Висвітлено основні науково-методичні підходи щодо розроблення та реалізації змісту Типової освітньої програми початкової освіти дітей із порушеннями інтелектуального розвитку для 1, 2 класів згідно з Концепцією Нової української школи. Обгрунтовано та представлено основну мету початкової освіти дітей із порушеннями інтелектуального розвитку, методичні підходи та принципи побудови програми, ключові компетентності та загальнонавчальні вміння, які закладено у ї̈ зміст програми. У програмі визначено відповідний зміст кожного навчального предмета чи інтегрованого курсу, вказано вимоги до конкретних очікуваних результатів навчання (предметно орієнтовані компетентності). Охарактеризовано основні складові інтегрованих курсів, як сучасних освітніх тенденцій; структуру програми: орієнтовний зміст навчального матеріалу, предметно-орієнтовані компетентності, життєва компетентність, які інформують учителя щодо результатів сформованості в учнів пізнавальних та соціально-адаптивних здібностей відповідно до мети та змістового наповнення галузі. Представлено методичні основи реалізації освітніх галузей та інтегрованих курсів.

Ключові слова: типова освітня програма, нова українська школа, зміст навчання, учні 3 порушеннями інтелектуального розвитку, ключові компетентності, загальнонавчальні уміння, життєва компетентність.

Елена Чеботарева, Институт специальной педагогики и психологии имени Николая Ярмаченко Национальной академии педагогических наук Украины, г. Киев, Украина Научно-методические подходы реализации содержания общего учащихся с нарушениями интеллектуального развития согласно концепции НУШ

Отражены основные научно-методические подходы к разработке и реализации содержания типовой образовательной программы для детей с нарушениями интеллектуального развития согласно Концепции Новой украинской школы. Обоснованы и представлены основные цели начального образования детей с нарушениями интеллектуального развития, методические подходы и принципы построения программы, представлены ключевые компетентности и общеучебные умения, которые заложены в содержание программы. B программе определены соответствующее содержание каждого учебного предмета или интегрированного курса, указано требования к конкретным ожидаемых результатов обучения (предметно-ориентированные компетентности). Автором представлены основные составляющие интегрированных курсов, как современных образовательных тенденций; структуру программы: ориентировочный содержание учебного материала, предметно-

() Чеботарьова 0., 2019 
ориентированные компетентности, жизненная компетентность», которые информируют учителя по результатам сформированности у учеников познавательных и социальноадаптивных способностей в соответствии с целью и содержательного наполнения отрасли. Представлены методические основы реализации образовательных областей.

Ключевые слова: типичная образовательная программа, новая украинская школа, содержание обучения, учащиеся с нарушениями интеллектуального развития, ключевые компетентности, общеучебные умения, жизненная компетентность.

Olena Chebotaryova, Mykola Yarmachenko Institute of Special Education and Psychology of The National Academy of Educational Sciences of Ukraine, Kyiv, Ukraine.

Scientific and methodical approaches to the implementation of pupils' education content with intellectual disabilities according to the concept of NUS

The article highlights the main scientific and methodological approaches to the development and implementation of the content of the Model educational program of primary education of children with intellectual disabilities for grades 1,2 according to the Concept of the New Ukrainian School. The basic purpose of primary education of children with intellectual disabilities, methodological approaches and principles of program construction are substantiated and presented, key competences and general educational skills that are embedded in the content of the program are presented. The program defines the relevant content of each course or integrated course and specifies the requirements for specific expected learning outcomes (subject-oriented competences). The main components of integrated courses are described as current educational trends; structure of the program: content of the educational material, subject-oriented competences, vital competences, which inform the teacher about the results of the formation of cognitive and social-adaptive abilities in the students in accordance with the purpose and content of the field. The methodological bases of realization of educational branches and integrated courses are presented.

Keywords: typical educational program, new Ukrainian school, content of education, students with intellectual disabilities, key competences, general skills, vital competence.

Кожна дитина, незалежно від ї здібностей, має право на успіх у житті, максимальне розкриття власних здібностей, яке може запропонувати якісна освіта.

(Нова українська школа)

Актуальним питанням сьогодення $є$ розроблення інноваційних стратегій навчання учнів з інтелектуальними порушеннями, підготовка іх до самостійної життєдіяльності та формування життєвої компетентності для успішної подальшої соціальної адаптації.

В умовах запровадження концепції Нової української школи виникає потреба в зміні освітніх пріоритетів щодо навчання дітей із порушеннями інтелектуального розвитку.

Провідним у Концепції Нової української школи є компетентнісний підхід, спрямований на оновлення змісту освіти, заснованого на формуванні необхідних життєвих компетентностей (Н. Бібік, Л. Ващенко, I. Срмаков, I. Зимня, О. Локшина, О. Овчарук, Л. Парамонова, О. Пометун, О. Савченко, А. Хуторський та ін.). Компетентнісний підхід визначає спрямованість освітнього проце-

«ОСОБЛИВА ДИТИНА: навчання і виховання», № 4, 2019 
су на досягнення результатів, якими є ієрархічно підпорядковані компетентності учнів: ключові, предметні та життєва [1;2 ].

Життєва компетентність, як здатність дитини з порушеннями інтелектуального розвитку в процесі інтегрування у соціальне оточення цілісно реалізовувати на практиці знання, досвід і цінності, набуті в процесі корекційно-розвивального навчання, набуває інтегративного значення в реалізації оновленого освітнього змісту.

Метою початкової освіти дітей із порушеннями інтелектуального розвитку є особистісне становлення учнів, розвиток їхніх пізнавальних здібностей, компетентностей та наскрізних умінь відповідно до вікових та індивідуальних психофізіологічних особливостей і потреб, формування цінностей та розвиток самостійності, творчості, пізнавальної активності, що забезпечують їню готовність до життя в демократичному суспільстві, продовження навчання в основній школі $[4 ; 5]$.

Реалізація цієї мети передбачає вирішення низки пріоритетних завдань, зокрема: забезпечення інноваційного змісту початкової освіти шляхом розроблення типових програм на основі компетентнісного підходу, створення освітнього середовища, що забезпечує доступність якісної освіти та успішну соціалізацію учнів.

Типову освітню програму для 1-2 класів для дітей із порушеннями інтелектуального розвитку розроблено відповідно до Закону України «Про освіту», Концепції Нової української школи, Державного стандарту початкової освіти (2018р.), з урахуванням Типових освітніх програм для закладів загальної середньої освіти, сучасних досягнень спеціальної педагогіки та психології щодо навчально-пізнавальних можливостей дітей із порушеннями інтелектуального розвитку[1;2;3, 4].

У програмі визначено вимоги до конкретних очікуваних результатів навчання (предметно-орієнтовані компетентності); вказано відповідний зміст кожного навчального предмета чи інтегрованого курсу. У пояснювальній записці до кожного предмета чи інтегрованого курсу представлено корекційно-розвивальні завдання та спрямованість навчального предмета, реалізація яких є обов'язковою умовою навчання.

Програму побудовано з урахуванням таких принципів:

- дитиноцентрованості і природовідповідності;

- корекційно-розвивальної спрямованості навчання;

- узгодження цілей, змісту і очікуваних результатів навчання;

- науковості, доступності і практичної спрямованості змісту;

- наступності і перспективності навчання;

- взаємозв'язаного формування ключових і предметних компетентностей;

- логічної послідовності й достатності засвоєння учнями предметних компетентностей;

- можливостей реалізації змісту освіти через предмети або інтегровані курси;

- творчого використання вчителем програми залежно від умов навчання;

- адаптації до індивідуальних особливостей, інтелектуальних і фізичних можливостей, потреб та інтересів дітей. 
Зміст програми має потенціал для формування в учнів з інтелектуальними порушеннями таких ключових компетентностей [5; 6]:

- володіння державною мовою; що передбачає елементарні вміння та навички (у межах мовленнєвих можливостей) усно і письмово висловлювати свої думки, усвідомлення ролі мови для спілкування та культурного самовираження;

- можливість спілкуватися рідною мовою (у межах пізнавальних можливостей), що передбачає використання рідної мови в різних комунікативних ситуаціях, зокрема в побуті, освітньому процесі, культурному житті громади;

- математична компетентність, що передбачає застосування (у межах пізнавальних можливостей) математичних знань і вмінь в особистому і суспільному житті людини;

- компетентності у галузі природничих наук, що передбачають формування пізнавального досвіду, прагнення самостійно чи в групі спостерігати та досліджувати, пізнавати себе і навколишній світ шляхом спостереження та дослідження;

- соціально-трудової компетентності, що передбачає формування трудових умінь та навичок, що забезпечують подальшу здатність до успішного опанування основ професійно-трудової діяльності, набуття навичок практичної життєдіяльності;

- екологічна компетентність, що передбачає сформованість уявлень щодо екологічного природокористування, дотримання правил природоохоронної поведінки, ощадного використання та збереження природних ресурсів;

- інформаційно-комунікаційна компетентність, що передбачає опанування елементарними основами цифрової грамотності для розвитку і спілкування, можливість безпечного використання інформаційно-комунікаційних засобів у навчанні та інших життєвих ситуаціях;

- навчання впродовж життя, що передбачає опанування життєво необхідними базовими вміннями і навичками, що сприятимуть подалышій соціальної адаптації та інтеграції в суспільство;

- громадянські та соціальні компетентності, що передбачає уміння діяти (у межах своїх можливостей) в життєвих ситуаціях, ідентифікувати себе як громадянина України, дбайливе ставлення до власного здоров'я та здоров'я інших людей, дотримання здорового способу життя;

- культурна компетентність, що передбачає залучення до різних видів мистецької творчості (образотворче, музичне та інші види мистецтв) шляхом розкриття і розвитку природних здібностей, творчого вираження особистості, формування навичок культури поведінки в соціумі;

- основи фінансової грамотності, що передбачає формування уявлень про грошові одиниці, необхідні для здійснення та організації побутової життєдіяльності, залучення до сфери соціально-побутової та елементарної економічної діяльності.

Спільними для всіх ключових компетентностей є такі вміння: спілкуватися, взаємодіяти та співпрацювати з дорослим та однолітками, сприймати інструкції та навчальні завдання, керувати емоціями, регулювати власну поведінку.

Враховуючи інтегрований характер компетентності, у процесі реалізації Типової освітньої програми рекомендується використовувати внутрішньопредметні і

«ОСОБЛИВА ДИТИНА: навчання і виховання», № 4, 2019 
міжпредметні зв’язки, які сприяють цілісності результатів початкової освіти та переносу вмінь у нові ситуаціі.

Вимоги до змісту навчання дітей з інтелектуальними порушеннями, котрі розпочинають навчання у початковій школі, мають враховувати досягнення попереднього етапу їхнього розвитку. Предметні компетентності для дітей з різним рівнем інтелектуальних порушень мають диференційований характер (для дітей 3 легким та помірним ступенем). Програмові компетенції для дітей з помірним ступенем інтелектуального порушення у Типовій програмі виокремлено під спеціальним позначенням - *. Зміст навчання для таких учнів добирається індивідуально, відповідно до їхніх пізнавальних можливостей.

Індивідуальна освітня траєкторія для учнів 3 помірним ступенем інтелектуального порушення охоплює предметний та соціально-орієнтований напрями навчання. Ключову роль відіграють не навчальні дисципліни, а предмети, що сприяють формуванню та розвитку життєво-необхідних навичок. Наскрізними корекційно-розвивальними напрями для дітей з помірним ступенем інтелектуального порушення є:

- розвиток навичок соціально-побутового орієнтування;

- формування навичок здорового способу життя;

- розвиток навичок самообслуговування;

- формування навичок комунікації;

- навчання побутовій ручній праці;

- навчання грамоті та елементарним рахунку.

Типову програму подано за табличною структурою, що складається з кількох колонок. У колонці «Орієнтовний зміст навчального матеріалу» подано оновлений та апробований у навчальних закладах для дітей із порушеннями інтелектуального розвитку зміст навчального матеріалу. Колонка «Предметно-орієнтовані компетентності» ознайомлює вчителя з переліком знань і вмінь, якими мають оволодіти учні в процесі навчання. Матеріали колонки «Життєва компетентність» інформують учителя щодо результатів сформованості в учнів пізнавальних та соціальноадаптивних здібностей відповідно до мети та змістового наповнення галузі.

Зберігаючи наступність із дошкільним періодом дитинства, початкова школа забезпечує подальше становлення особистості дитини, іï фізичний, інтелектуальний, соціальний розвиток; формує здатність до творчого самовираження, розвитку пізнавальної діяльності, виховує ціннісне ставлення до держави, рідного краю, української культури, пошанування своєї гідності та інших людей, збереження здоров'я.

Згідно із Законом України «Про освіту», на основі Державного стандарту й Типової освітньої програми заклади освіти, наукові установи та інші суб'єкти освітньої діяльності можуть розробляти освітні програми - єдиний комплекс освітніх компонентів (предметів, індивідуальних проектів, контрольних заходів тощо), спланованих і організованих для досягнення визначених результатів навчання. Освітні програми можуть відрізнятися від Типової освітньої програми послідовністю викладання навчального матеріалу, обсягом його вивчення, наявністю додаткових компонентів змісту або використанням оригінальних форм, методів і засобів навчання [5; 6]. 
Розподіл навчальних годин за темами, розділами, вибір форм і методів навчання вчитель визначає самостійно, враховуючи пізнавальні здібності та можливості учнів з порушеннями інтелектуального розвитку, конкретні умови роботи, забезпечуючи водночас досягнення корекційно-розвивальних завдань та орієнтовних очікуваних результатів, зазначених у програмі.

Упродовж навчання в початковій школі учні навчаються способам самоконтролю, що сприяє вихованню відповідальності, розвитку інтересу, своєчасному виявленню прогалин у знаннях, уміннях, навичках та їх корекції.

Навчальні досягнення учнів з порушеннями інтелектуального розвитку у 1-2 класах підлягають вербальному оцінюванню [3]. Важливим є аналізувати хід реалізації навчальної програми й ухвалювати рішення щодо коригування програми і методів навчання відповідно до індивідуальних потреб дитини; мотивувати прагнення здобути максимально можливі результати; виховувати ціннісні якості особистості, бажання навчатися, не боятися помилок, переконання у власних можливостях і здібностях.

Зазначимо, що основною новацією, яка входить у практику навчання учнів 3 інтелектуальними порушеннями 1-2 класів, є структурування змісту початкової освіти на засадах інтегрованого підходу в навчанні. Дидактичний зміст процесу інтеграції полягає у взаємозв'язку змісту, методів і форм роботи. Відповідно інтеграцію навчального матеріалу з різних навчальних предметів здійснюють навколо певного об'єкту чи явища довкілля, або навколо розв'язання проблеми міжпредметного характеру, або для створення творчого продукту тощо [7; 8].

Так, освітня «Мовно-літературна» галузь реалізується у 1 класі інтегрованим курсом «Навчання грамоти», який спрямований на формування у першокласників елементарних навичок читання і письма, розвиток базових комунікативних умінь, пізнавальних здібностей, здатності спілкуватися українською мовою в особистому й суспільному житті.

Для реалізації зазначеної мети у Типовій освітній програмі в рамках вивчення курсу виділено такі змістові лініі: «Взаємодіємо усно та з допомогою альтернативних засобів комунікачії», «Навчаємось читати», «Взаємодіємо писвмово», «Навчаємось сприймати медіа» [5; 6].

У процесі навчання грамоти створюються передумови для мовленнєвого, інтелектуального розвитку, формування морально-естетичних уявлень і понять, збагачення почуттів, виховання потреби у спілкуванні, що є підгрунтям для повноцінної соціалізації дітей з інтелектуальними порушеннями.

Водночас із розвитком основних видів мовленнєвої діяльності ключовою позицією є реалізація корекційно-розвивальних завдань, спрямованих на корекцію порушень пізнавальної діяльності (сприймання, уяви, пам'яті, уваги, мовлення, мислення), емоційно-вольової сфери, розвитку артикуляційної моторики та координації рухів тощо.

Спеціальним завданням інтегрованого курсу «Навчання грамоти» визначено формування та корекцію зв’язного мовлення, що має відбуватися в тісному зв'язку з розвитком пізнавальної, сенсорної діяльності дітей на основі розвитку предметно-дійового, наочно-образного, словесно-логічного мислення, спостереж-

«ОСОБЛИВА ДИТИНА: навчання і виховання», № 4, 2019 73 
ливості, уваги тощо. Отже, зміст цього навчального предмета, з метою посилення його компенсаторно-корекційних та розвивальних функцій, має комунікативно-практичну спрямованість: містить фактичний матеріал, опанування якого має забезпечити формування комунікативних умінь, конкретизацію в слові чуттєвого і практичного досвіду учнів, розвиток основних пізнавальних процесів на предметно-практичній і вербальній основі.

Отже, навчання учнів 1 класу здійснюється через інтегрований курс «Навчання грамоти»; 2 класу - через навчальні предмети «Українська мова», «Читання» або інтегрований курс цих навчальних предметів.

Новим у змісті освіти для учнів з інтелектуальними порушеннями є інтегрований курс «Я досліджую світ», який поєднав природничу, соціальну i здоров'язбережувальну, громадянську та історичну галузі. Зазначені освітні галузі можуть реалізовуватись окремими предметами або в інтегрованому курсі за різними видами інтеграції (тематична, процесуальна, міжгалузева; у межах однієї галузі; на інтегрованих уроках, під час тематичних днів, у процесі проектної діяльності) за активного використання міжпредметних зв'язків, організації різних форм взаємодії учнів. Для розв'язання учнями практичних завдань у життєвих ситуаціях залучаються навчальні результати з інших освітніх галузей.

Метою навчального курсу «Я досліджую світ» $е$ особистісний розвиток молодших учнів на основі формування цілісного образу світу в процесі засвоєння різних видів соціального досвіду, який охоплює систему інтегрованих знань про природу і суспільство, ціннісні орієнтації в різних сферах життєдіяльності та соціальної практики, способи дослідницької поведінки, які характеризують здатність учнів розв'язувати практичні задачі.

Вирішення завдань курсу забезпечується освітньою та корекційно-розвивальною змістовими лініями побудови навчального матеріалу.

Так, освітня мета реалізується за допомогою наступних змістових ліній:

- Людина (пізнання себе, своїх можливостей; здорова і безпечна поведінка);

- Людина в суспільстві (стандарти поведінки в сім'ї, в суспільстві; моральні норми; навички співжиття і співпраці; громадянські права та обов'язки як члена суспільства. Пізнання свого краю, історії, символів держави. Внесок українців у світові досягнення);

- Людина i природа (цілісність природи, взаємозв'язок об'єктів і явищ, відповідальна діяльність людини у природі, залежність між діяльністю людини і станом довкілля).

Корекційно-розвивальна спрямованість курсу забезпечується на основі пізнавального, сенсомоторного, мовленнєвого, особистісного розвитку учнів, що передбачає розвиток навичок аналізу, планування, організації, власне виконання та самоконтролю діяльності під час проведення практичних робіт у класі, у живому куточку, на присадибній ділянці; усвідомлення неповторності й самоцінності кожної людини; спостереження традицій і звичаїв українського народу; дотримання правил поведінки у родині, колективі, суспільстві.

У типовій освітній програмі запропоновано інтегрований курс «Мистецтво», метою якого є художньо-естетичний розвиток особистості дитини з порушеннями 


\section{BEKSOP TPAHROCOPMANUIII}

інтелектуального розвитку, освоєння нею культурних цінностей у процесі пізнання мистецтва; плекання пошани до вітчизняної та зарубіжної мистецької спадщини.

Реалізація поставленої мети здійснюється за змістовими лініями: «Художнъо-творча діяльність», «Сприймання та інтерпретація мистецтва», «Комунікація через мистещтво», які окреслюють одну з моделей досягнення загальних цілей освітньої галузі та розкривають основну місію загальної мистецької освіти.

Корекційно-розвивальна мета навчального курсу передбачає формування життєтворчості особистості на основі використання засобів навчання, які сприяють удосконаленню вищих психічних функцій, виробленню іх усвідомленості та довільності. Основними корекційно-розвивальними напрямами у формуванні мистецьких знань є розвиток пізнавальної, сенсомоторної, особистісної сфер дитини, що передбачає формування естетичного смаку, емоційної сфери, розширення соціального та естетичного досвіду. Процес навчання відбувається на основі активізації творчої діяльності особистості, що сприятиме цілісному та всебічному розвитку учнів.

Мистецька освітня галузь може реалізуватися через інтегровані курси або предмети вивчення за окремими видами мистецтва: наприклад, музичне мистецтво, образотворче мистецтво тощо за умови реалізації упродовж циклу навчання всіх очікуваних результатів галузі.

Отже, впровадження інноваційного змісту, що передбачає використання в практиці навчання типової освітньої програми для дітей з порушеннями інтелектуального розвитку, дає змогу вчителеві самостійно обирати й формувати інтегрований та автономний спосіб подання змісту із освітніх галузей Стандарту, добирати дидактичний інструментарій, орієнтуючись на індивідуальні пізнавальні запити і можливості учнів (рівень навченості, актуальні стани потреб, мотивів, цілей, сенсорного та емоційно-вольового розвитку). Особливого значення у дидактико-методичній організації навчання надається його зв'язку 3 життям, 3 практикою застосування здобутих уявлень, знань, навичок поведінки в життєвих ситуаціях. Обмеженість відповідного досвіду учнів з порушеннями інтелектуального розвитку потребує постійного залучення й аналізу їхніх вражень, чуттєвої опори на результати дослідження об'єктів і явищ навколишнього світу. Педагогічна стратегія, яка опирається на наслідувальні механізми у розвитку пізнавальних процесів молодших школярів, і передбачає пріоритетне використання наочності, зорових опор, зразків, алгоритмів, поетапного контролю, збагачується полісенсорним підходом, що зумовлює активізацію пізнавально-комунікативної діяльності учнів, сприймання ними властивостей і якостей предметів і явищ природного і соціального оточення, здійснення пошукової діяльності, що в цілому сприяє ефективному формуванню ключових та предметних компетентностей учнів.

\section{ЛITEPATYPA}

1. Закон України про освіту http://zakon2.rada.gov.ua/laws/show/2145-19

2. Концепція НУШ: https://mon.gov.ua

«ОСОБЛИВА ДИТИНА: навчання і виховання», № 4, 2019 75 
3. Критерії оцінювання навчальних досягнень учнів початкових класів 3 порушеннями інтелектуального розвитку / навч.-метод. посібник / авт.: О. В. Чеботарьова, Г. О. Блеч, I. В. Гладченко, С. В. Трикоз, І. В. Бобренко та ін.: За ред.: О. В. Чеботарьової, І. В. Гладченко. - К., ІСП НАПН України, 2016. - 87 с. - Електронний доступ: http://ib.iitta.gov.ua/id/ eprint/707790

4. Державний стандарт: https://www.kmu.gov.ua/ua/npas/prozatverdzhennya-derzhavnogostandartu-pochatkovoyi-osviti

5. Типова освітня програма початкової освіти спеціальних закладів загальної середньої освіти для учнів 1 класів з інтелектуальними порушеннями (2018) [Режим доступу: http:// lib.iitta.gov.ua/id/eprint/71142]

6. Типова освітня програма початкової освіти спеціальних закладів загальної середньої освіти для учнів 2 класів з інтелектуальними порушеннями (2019) [Режим доступу: https:// lib.iitta.gov.ua/716955/; http://ispukr.org.ua/?p=4091\#.XYEvvqUYDMw]/

7. Чеботаръова О. В. Реалізація компетентнісного підходу у навчанні школярів з порушеннями інтелектуального розвитку /О. В.Чеботарьова //Діти з особливими потребами в освітньому просторі: збірник матеріалів V Міжнародного конгресу зі спеціальної педагогіки, психології та реабілітології «Діти з особливими потребами в освітньому просторі», 10-11 жовтня 2019 року, Чернігів (Національний університет «Чернігівський колегіум» імені Т. Г. Шевченка). - Київ: Симоненко І. В., 2019. - С. 197-201.

8. Чеботарьова О. В. Теоретичні та методичні основи реалізації змісту освіти дітей з порушеннями інтелектуального розвитку // Теорія і практика спеціальної педагогіки та психології: збірник наукових праць. Вип. 9. К., 2018. С. 75-80.

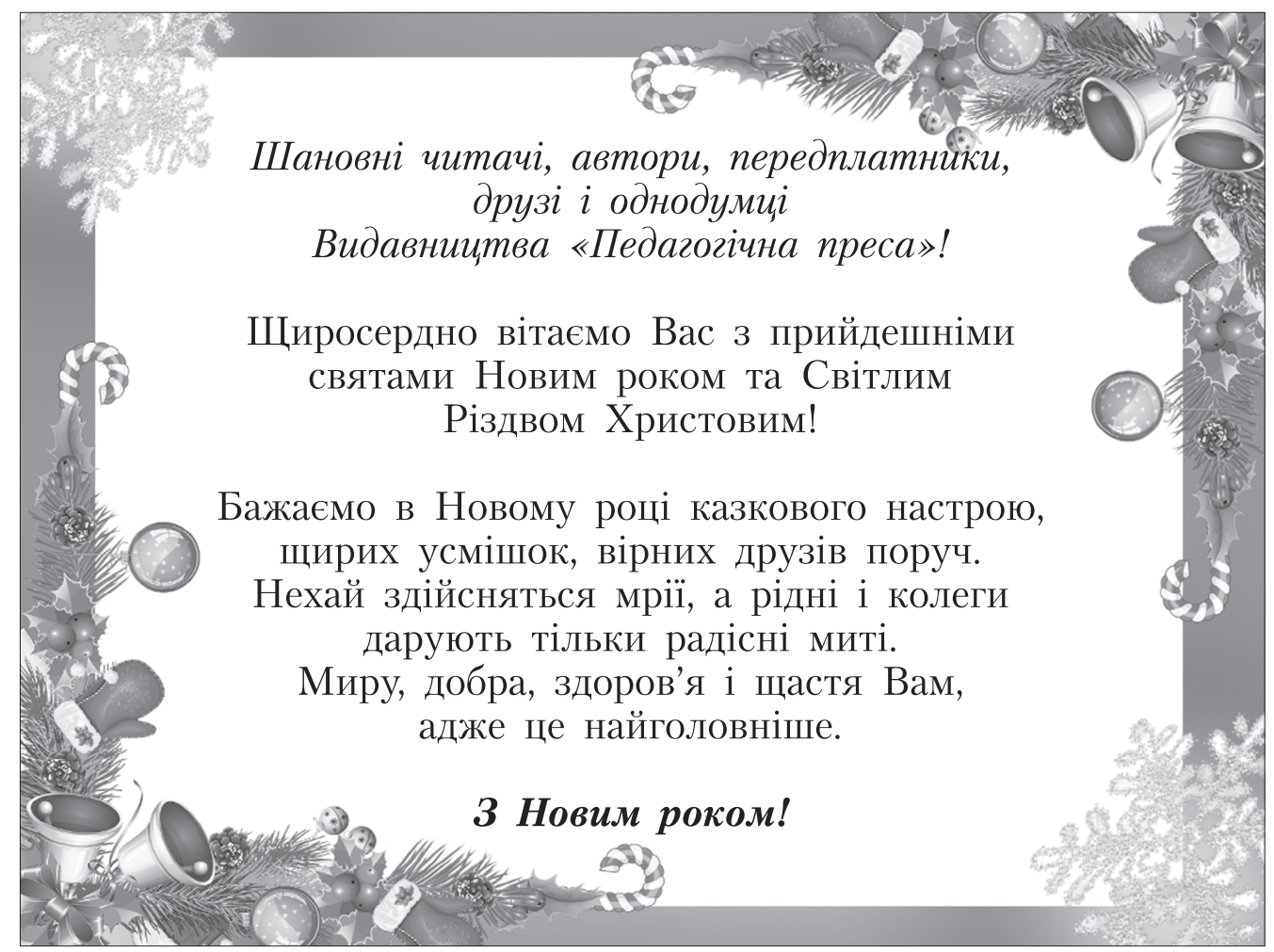

